\title{
OCCURRENCE OF ACUTE PARALYSIS VIRUS OF THE HONEY BEE (APIS MELLIFERA) IN A HUNGARIAN APIARY INFESTED WITH THE PARASITIC MITE VARROA JACOBSONI
}

\author{
L. BÉKÉSI $^{1 *}$, Brenda V. BALL ${ }^{2}$, M. DOBOS-KOVÁCs ${ }^{3}$, T. BAKONYI $^{4}$ and M. RUSVAI ${ }^{4}$ \\ ${ }^{1}$ Department of Parasitology and Zoology, ${ }^{3}$ Department of Pathology and Forensic \\ Veterinary Medicine, ${ }^{4}$ Department of Microbiology and Infectious Diseases, University \\ of Veterinary Science, H-1400 Budapest, P.O. Box 2, Hungary; ${ }^{2}$ Department of \\ Entomology and Nematology, IACR-Rothamsted, Harpenden, Herts., U. K.
}

(Received February 1, 1999; accepted March 8, 1999)

\begin{abstract}
Viruses of the honey bee have been known for a long time; however, recently the attention of scientists and apiculturalists has turned towards the relationship between these viruses and the parasitic mite Varroa jacobsoni. Although clinical symptoms indicated the presence of some of the viruses of bees in Hungary, none have previously been isolated or identified. During July unusual adult bee and brood mortality was observed in some colonies of an apiary in Budapest known to be infested with Varroa jacobsoni. Large amounts of acute paralysis virus (APV) were detected serologically in healthy honey bee pupae killed by the injection of a bacteria-free extract of diseased adult bees. Crystalline arrays of $30 \mathrm{~nm}$ particles were seen in ultrathin sections of the tissues of injected pupae and naturally infected adult bees. In spite of the application of acaricide treatments the bee population in several colonies had collapsed by the end of summer and the apiary suffered severe wintering losses.
\end{abstract}

Key words: Honey bee, acute paralysis virus, Varroa jacobsoni

Viruses can replicate in all types of living cells ranging from bacteria through to cells of invertebrates and the various cell types of higher mammals. The first non-occluded insect virus, sacbrood, was first recognised by White in 1917 in honey bee larvae and later isolated and characterised by Bailey et al. (1964). Intensive study since that time has shown the honey bee to be a primary source of picorna-like viruses in insects, with 18 viruses detected so far (Allen and Ball, 1996). Viruses persist in the bee population at a low level of inapparent infection: clinical symptoms appear only when virus replication is initiated and infection becomes systemic. Infected cells can no longer perform their essential function and their mass destruction leads to disturbances in the function of vital organs. Outbreaks of

*E-mail: lbekesi@ns. univet.hu; Fax: (36-1) 342-7701 
severe disease due to virus infection are relatively uncommon because transmission is limited by the death of infected individuals away from the colony, by the short life span of bees during summer and by various defence mechanisms (e.g. hygienic behaviour). Conversely, virus spread can be facilitated by a range of other factors such as dysentery, infection with Nosema apis and overcrowded conditions. In recent years the spread of Varroa jacobsoni almost world wide has focused attention on the viruses of bees because of the role of the mite in the transmission of a number of these infections and their association with colony mortality (Ball and Allen, 1988; Kulincevic et al., 1990; Hung et al., 1995).

\section{Materials and methods}

From late July 1997, a Budapest beekeeper observed sporadic adult bee mortality in his colonies. Eight to ten-day-old bees undertaking orientation flights were the first to show symptoms of crawling and paralysis and some individuals had distended abdomens and appeared dysenteric.

An aqueous homogenate of 30 dead bees collected from the apiary was heat fixed and tested for $N$. apis infection by staining first with $0.4 \%$ methylene blue for $15 \mathrm{~min}$ and then with $0.6 \%$ fuchsin solution for several seconds.

Subsequently, bacterium-free extracts were prepared from diseased living bees according to the method described by Bruce et al. (1995). The bees were collected from three affected colonies (112, 93 and 121 living bees, respectively) and exterminated with an overdose of $\mathrm{CO}_{2}$. At the end of the process the three samples were resuspended in 1-1 $\mathrm{ml}$ PBS and $0.5 \mathrm{ml}$ of each was unified (combined stock suspension). Tenfold serial dilutions of the combined suspension were filtered through $200 \mathrm{~nm}$ pore size Nalgene filters and three groups of 40 eight to ten-dayold, white or light brown eyed pupae from symptomless colonies of the same apiary were injected intra-abdominally with $10 \mu 1$ of the stock suspension, the 1:10 and the 1:100 dilutions. The pupae were maintained in an incubator at $35{ }^{\circ} \mathrm{C}$ and each day three of them were fixed for histological examination. The samples were pre-fixed with $4 \%$ paraformaldehyde, post-fixed with $1 \%$ osmium tetroxide, embedded in Durcupan, and ultrathin sections were made.

On the fourth day after inoculation 20 pupae from each group were homogenized in PBS and a suspension was prepared according to the method described above. The samples were ultracentrifuged for $3 \mathrm{~h}$ at 130,000 $\mathrm{g}$ in a Sorvall Combi Plus ultracentrifuge, and the pellets were resuspended in $2 \mathrm{ml} P B S$. This suspension was layered onto a caesium chloride gradient $(1.2-1.5 \mathrm{~g} / \mathrm{ml})$, and centrifuged at the same velocity for $24 \mathrm{~h}$. At the end of this period two wellvisible bands were formed in the gradient $(1.32-1.33$ and $1.37-1.38 \mathrm{~g} / \mathrm{ml}$, respectively). The bands were separated by fractioning and dialysed overnight 
against PBS. The purified virus suspensions were tested by immunodiffusion against antisera to six different $30 \mathrm{~nm}$ honey bee viruses (Allen and Ball, 1996). Samples taken from the above two bands were counterstained with uranyl acetate and lead citrate and examined in a JEM-JEOL 100S transmission electron microscope.

\section{Results}

On dissection of naturally diseased bees, the only pathological finding was the distension of the honey sac and large intestine. No $N$. apis infection could be detected in these bees. During a detailed colony health inspection carried out at the end of August many dead larvae were found and numerous adult female $V$. jacobsoni were seen on the adult bees. By the end of September the bee population in the affected colonies had dramatically declined. Despite the application of an acaricide treatment, 16 out of the 45 colonies were in poor condition before wintering.

Ultrathin sections of various organs of the affected bees and experimentally infected pupae revealed the presence of virus particles $30 \mathrm{~nm}$ in diameter, in crystalline arrays, in the cytoplasm of cells (Fig. 1).

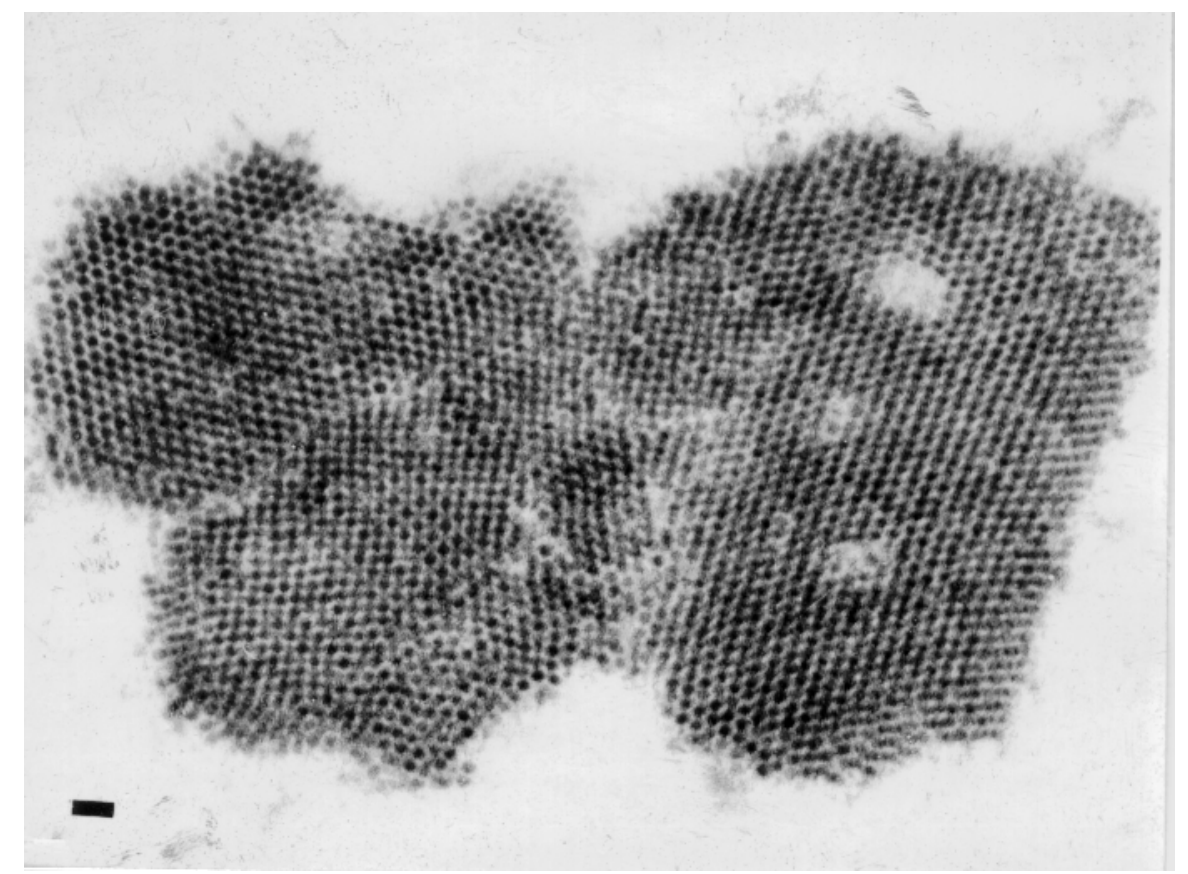

Fig. 1. Group of $30 \mathrm{~nm}$ virus particles in crystalline array in the cytoplasm of a cell of an experimentally infected pupa. $\mathrm{Bar}=100 \mathrm{~nm}$ 
Masses of virus particles of similar size were observed in the extract of experimentally infected pupae purified by caesium chloride gradient centrifugation and negatively stained (Fig. 2). The upper band of the caesium chloride gradient (band A: $1.32-1.33 \mathrm{~g} / \mathrm{ml}$ ) gave no reaction when tested by immunodiffusion against six different honey bee virus antisera and no virus particles were visualised by electron microscopy. The material was probably of host origin. The lower band (band B: $1.37-1.38 \mathrm{~g} / \mathrm{ml}$ ) gave a strong positive reaction only against acute paralysis virus (APV) antiserum by immunodiffusion.

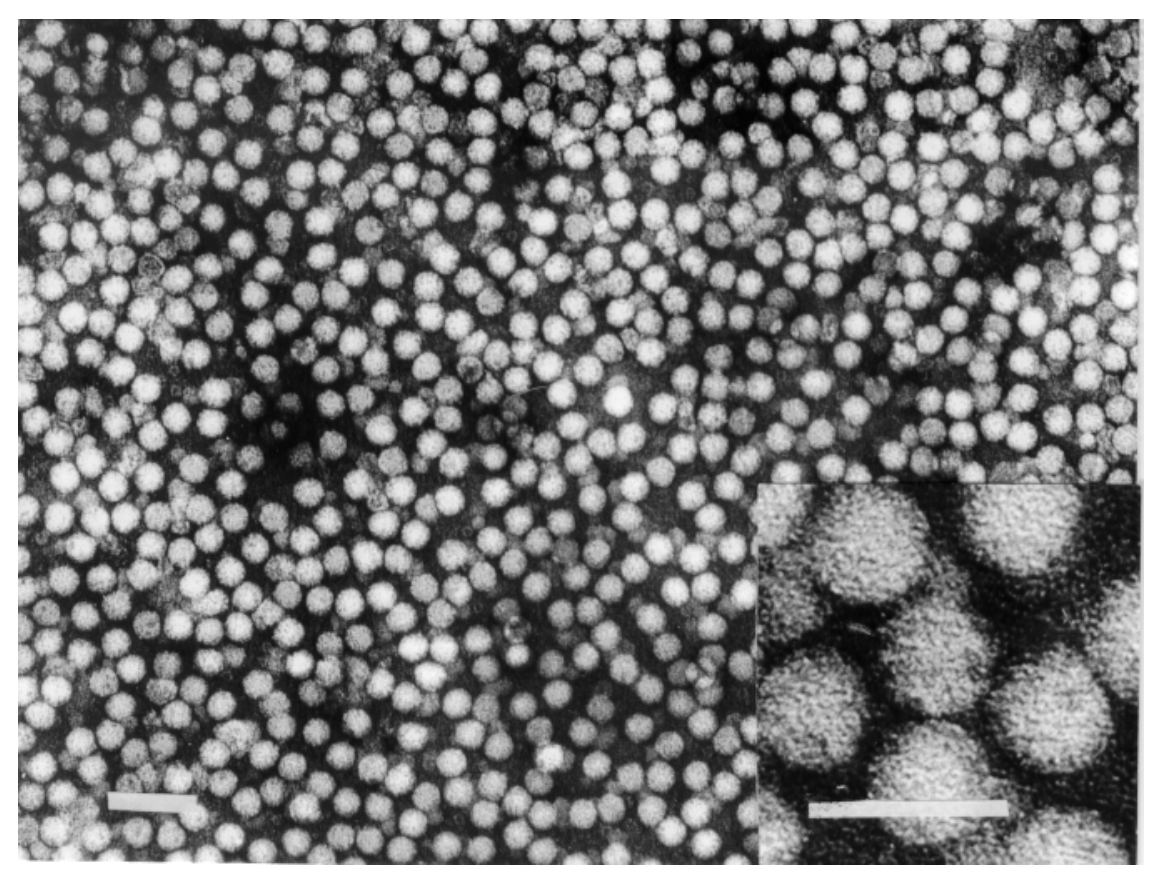

Fig. 2. Acute paralysis virus (APV) particles extracted from experimentally infected pupae purified in a caesium chloride gradient. $\mathrm{Bar}=100 \mathrm{~nm}($ Inset bar $=50 \mathrm{~nm})$

\section{Discussion}

Information on the incidence and world distribution of honey bee viruses is still patchy and incomplete (Allen and Ball, 1996). Of the viral diseases, chronic bee paralysis and, according to earlier data, sacbrood, have long been suspected to be present in Hungary based on clinical symptoms; however, due to the limited availability of specific antisera it has not been possible to confirm their presence serologically (Szücs, 1973; Koltai, 1985; Békési and Rusvai, 1998). 
Acute paralysis virus (APV) was originally discovered during laboratory infection experiments (Bailey et al., 1963) and, until recently, was never associated with disease or mortality of bees in nature. However, the virus is commonly present in small amounts in apparently healthy bees, especially in the summer, but it may normally only be detected indirectly, by sensitive infectivity tests (Bailey et al., 1981). By this means APV has been detected in live adult bees in France, Italy, Canada, New Zealand and Australia. In contrast, large amounts of APV have been detected directly, by serology, in individual dead adult bees and brood from colonies in several countries in Europe and in the USA severely infested with $V$. jacobsoni. The evidence from a number of different sources suggests that APV infection is linked to the mortality of mite-infested colonies (Kulincevic et al., 1990). Laboratory experiments have also demonstrated that the mite acts as a virus vector and can transmit infection from severely infected individuals to healthy bees and brood.

In the investigations reported here APV was not detected directly by serology in dead or diseased adult bees or brood from the affected colonies and unequivocal proof of the cause of the observed mortality has not been established. However, ultrathin sections of the tissues of naturally infected bees revealed the presence of crystalline arrays of virus particles of the same size as APV. The field symptoms also suggested a paralytic disease.

Like most virus diseases, the virus diseases of bees cannot be controlled by medication. Treatment of the underlying problem may bring improvement in viral infections that occur in close association with specific pathogens or syndromes. Thus, the control of $N$. apis diminishes the severity of infection caused by black queen cell virus (BQCV), bee virus Y (BVY) and filamentous virus (FV), and the prevention of dysentery or the elimination of its cause has a similar effect on infection by bee virus X (Bailey and Ball, 1991; Allen and Ball, 1996). In laboratory experiments the mite $V$. jacobsoni has been shown to transmit a number of unrelated honey bee viruses (Ball, 1989) but it is likely that those which predominate and which are economically important in nature are infective for both adult bees and pupae by introduction into the haemolymph. Therefore, effective control of the parasitic mite is essential to reduce colony mortality due to associated virus infections (Békési and Rusvai, 1998).

As $V$. jacobsoni is regarded as a source of major economic losses in Hungary, it is important that the factors aggravating these losses and potentially contributing to severe bee mortality be elucidated. An effective control strategy can be developed only by establishing a precise diagnosis and by ruling out other causative agents in all cases. Further studies are needed to determine the incidence and prevalence of bee viruses in Hungary and their contribution to the mortality of colonies infested with the mite. 


\section{Acknowledgements}

We wish to express our thanks to the Department of Apiculture, Institute for Small Animal Research (Gödöllő), and especially to Mrs Enikő Sz. Mátray, Head of Department, for the help rendered during this work. The investigations were partly supported by grant no. OTKA C 077 of the Hungarian Scientific Research Fund.

\section{References}

Allen, M. F. and Ball, B. V. (1996): The incidence and world distribution of honey bee viruses. Bee World 77, 141-162.

Bailey, L. and Ball, B. V. (1991): Honey Bee Pathology. Acad. Press, London, 193 pp.

Bailey, L., Ball, B. V. and Perry, J. N. (1981): The prevalence of viruses of honey bees in Britain. Ann. Appl. Biol. 97, 109-118

Bailey, L., Gibbs, A. J. and Woods, R. D. (1963): Two viruses from the adult honey bee (Apis mellifera Linnaeus). Virology 21, 390-395.

Bailey, L., Gibbs, A. J. and Woods, R. D. (1964): Sacbrood virus of the larval honey bee (Apis mellifera Linnaeus). Virology 23, 425-429.

Ball, B. V. (1989): Varroa jacobsoni as a virus vector. In: Present status of varroatosis in Europe and progress in the varroa mite control. Proceedings of a meeting of the EC-Experts group, Udine, Italy. EUR 11932

Ball, B. V. and Allen, M. F. (1988): The prevalence of pathogens in honey bee (Apis mellifera) colonies infested with the parasitic mite Varroa jacobsoni. Ann. Appl. Biol. 113, 237-244.

Békési, L. and Rusvai, M. (1998): About the viruses of honey bees (Apis mellifera) - Review article (in Hungarian, with English abstract). Magyar Állatorvosok Lapja 120, 364-369.

Bruce, W. A., Anderson, D. L., Calderone, N. W. and Shimanuki, H. (1995): Survey for Kashmir bee virus in honey bee colonies in the United States. Am. Bee J. 135, 352-355.

Hung, A., Adams, J. R. and Shimanuki, H. (1995): Bee parasitic mite syndrome (II): the role of Varroa mite and viruses. Am. Bee J. 135, 702-704.

Koltai, L. (ed.) (1985): Prevention and Treatment of Honey Bee Diseases (in Hungarian). Mezőgazdasági Kiadó, Budapest, 233 pp.

Kulincevic, J., Ball, B. and Mladjan, V. (1990): Viruses in honey bee colonies infected with Varroa jacobsoni: first findings in Yugoslavia. Acta Veterinaria Beograd 40, 37-42.

Szücs, L. (ed.) (1973): Honey Bee Health and Diseases (in Hungarian). Mezőgazdasági Kiadó, Budapest, $248 \mathrm{pp}$.

White, G. F. (1917): Sacbrood. Bulletin, US Department of Agriculture, No. 431. 